\title{
Growth and Initial Development of Papaya Plants (Sunrise Solo) in Different Concentrations of Biostimulants
}

\author{
Bruno Anderson Araujo Barros ${ }^{1}$, Sammy Sidney Rocha Matias ${ }^{2}$, Thamyres Yara Lima Evangelista ${ }^{3}$, \\ Mariane Sirqueira Nogueira ${ }^{1}$, Thaís Paula Martins Nunes ${ }^{3}$, Gasparino Batista de Sousa ${ }^{2}$ \\ $\&$ Gustavo Alves Pereira ${ }^{4}$ \\ ${ }^{1}$ Agronomic Engineering, State University of Piauí, Corrente, Brazil \\ ${ }^{2}$ Doctor of Agronomy, State University of Piauí, Corrente, Brazil \\ ${ }^{3}$ Master of Agrarian Sciences, Federal University of Piauí, Bom Jesus, Brazil \\ ${ }^{4}$ Doctor of Agronomy, Federal University of Piauí, Bom Jesus, Brazil \\ Correspondence: Gustavo Alves Pereira, Coordination of the Graduate Program in Agricultural Sciences, Center \\ for Agrarian Sciences, Federal University of Piauí, BR 135, km 03, s/n. Neighborhood Planalto Horizonte \\ 64900-000, Bom Jesus/PI, Brazil. Tel: (89)-99904-7252. E-mail: thamyresevangelista@outlook.com
}

Received: March 23, 2020

doi:10.5539/jas.v12n6p189
Accepted: May 2, $2020 \quad$ Online Published: May 15, 2020

URL: https://doi.org/10.5539/jas.v12n6p189

\begin{abstract}
The objective of this research was to evaluate the vegetative growth of papaya seedlings, propagated by seeds, regarding the use and application rates of two biostimulants in two types of soil. The experiment was carried out at the State University of Piauí (UESPI)/Campus de Corrente, with papaya (Carica papaya L.) as a research culture, on a screen at $50 \%$ brightness. The completely randomized design consisted of four treatments arranged according to the following application doses $(0,4,8,12$, and $16 \mathrm{ml})$ using the biostimulant Solofull ${ }^{\circledR}$ and Stimulate $^{\circledR}$ via soil, with six replicates per treatment, totaling 24 experimental units. The soil used came from two situations, soil 1 (area in process of degradation, Gilbués-PI) and soil 2 (pasture area, Corrente, PI). At 65 days after sowing, height, stem diameter, number of true leaves, leaf area, height ratio of plants, and stem diameter and root length were evaluated. The data were submitted to analysis of variance. The degraded area soil provided the best growth of the aerial part. The types of biostimulants and application doses used in this study did not provide significant differences between treatments.
\end{abstract}

Keywords: Carica papaya L., soil, hormonal stimulant, seedling production

\section{Introduction}

Papaya (Carica papaya L.) is one of the main fruits grown in tropical and subtropical regions. Brazil is the world's second largest producer of fruit with 1,517 t/year (FAO, 2017). Since the Northeast region is responsible for $59.45 \%$ of the quantity produced, followed by the Southeast (34.85\%), North (4.72\%), Midwest $(0.70 \%)$ and South $(0.28 \%)$, respectively (IBGE, 2018). This is due to the techniques applied in the management of the culture, among them, the production of seedlings.

The papaya seedling production process is one of the most important stages of the production system. Because, the use of good techniques in the initial development of the plant guarantees the precocity and productivity of the crop (Costa Júnior et al., 2017). Papaya can be propagated through seeds or vegetatively (cutting and grafting) (Nguyen \& Yen, 2018).

However, seed propagation is the most commercially used method in Brazil, since it is an accessible and practical procedure (Nguyen \& Yen, 2018). However, it presents problems, such as slow and irregular germination, due to the presence of sarcotest in the seeds (Jesus et al., 2015), and dormancy associated with the maturation and harvesting time of the fruits (Melo et al., 2015), resulting in the increase of the cost of seeds and, consequently, high cost of production, and final value of the product.

In addition, after 3 years of planting the orchard must be renewed, as the management of the plants becomes uneconomical, due to the decrease in fruit production and quality. As a result, new technologies have been adopted 
in the papaya culture in order to increase productivity levels and minimize production costs (Guimarães et al., 2012).

The use of growth inducers as bioregulatory agents is a promising alternative (Lessa et al., 2013). Biostimulants, depending on their composition, concentration, and proportion of substances, can increase plant growth and development, stimulating cell division, differentiation, and cell extension (Du Jardim, 2015).

In addition to increasing the absorption and use of water and nutrients by plants (Sá et al., 2013), it promotes their hormonal balance (Calvo, Nelson, \& Kloepper, 2014). Biostimulants are the substances that act in different parts of the plant, with variable effects depending on the environmental conditions, the species, the stage of development, and the concentration of the product.

In agriculture, this practice has become increasingly common, due to the direct action of production optimizing agents, which act within the plant cells (Guimarães et al., 2015). Currently, several research studies have been developed with the use of biostimulants in agriculture, especially in grain production, with a lack of data in the production of fruit seedlings.

Thus, the objective of this work was to verify the vegetative growth of papaya seedlings, propagated by seeds, regarding the use and application doses of two biostimulants in two types of soil.

\section{Method}

\subsection{Study Area Description}

The study was conducted in 2018, from September to November on a $50 \%$ brightness screen, at the State

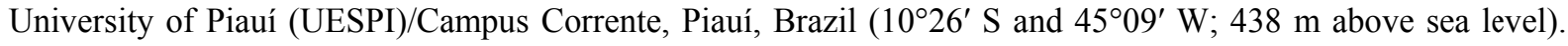
The region climate classified as Aw (tropical wet) with dry winter season (Koppen \& Geiger, 1928).

The climatic data during the experiment were obtained by the Brazilian Institute of Meteorology (INMET, 2018), and are shown in Figure 1. The average annual rainfall was $925 \mathrm{~mm}$, with an annual mean temperature of $24.8^{\circ} \mathrm{C}$.

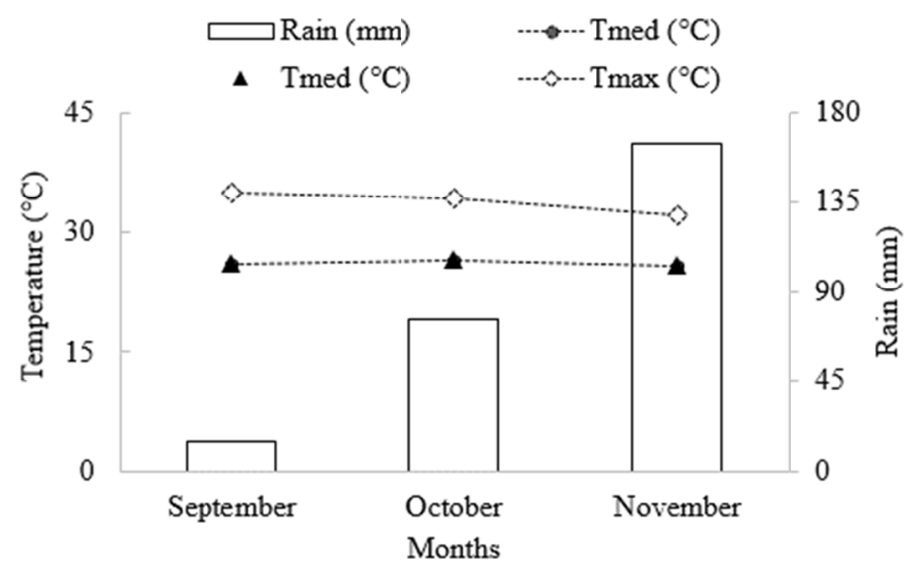

Figure 1. Climatic data, maximum temperature $(\operatorname{maxT})$, mean $(\operatorname{medT}), \operatorname{minimum}(\operatorname{minT})$ and rainfall, Corrente-PI

The soil was classified as Yellow Latosol (Santos et al., 2018), and its physical and chemical characteristics are shown in Table 1. 
Table 1. Chemical and physical characteristics of the soil at $0.0-0.20 \mathrm{~m}$ depth

\begin{tabular}{lll}
\hline Soil characteristic & Soil degraded (Gilbués PI) & Soil pasture (Corrente PI) \\
\hline $\mathrm{pH}($ in water) & 8.4 & 6.4 \\
$\mathrm{Ca}^{2+}\left(\mathrm{cmolc} \mathrm{dm}^{-3}\right)^{\mathrm{b}}$ & 20.3 & 2.92 \\
$\mathrm{H}+\mathrm{Al}^{3+}\left(\mathrm{cmolc} \mathrm{dm}^{-3}\right)$ & 0.00 & 1.14 \\
$\mathrm{~K}^{+}\left(\mathrm{cmolc} \mathrm{dm}^{-3}\right)$ & 0.32 & 0.91 \\
$\mathrm{Mg}^{2+}\left(\mathrm{cmolc} \mathrm{dm}^{-3}\right)^{\mathrm{b}}$ & 4.83 & 1.88 \\
$\mathrm{~T}\left(\mathrm{cmolc} \mathrm{dm}^{-3}\right)$ & 25.42 & 6.85 \\
$\mathrm{SB}\left(\mathrm{cmolc} \mathrm{dm}^{-3}\right)$ & 25.42 & 5.71 \\
$\mathrm{P}\left(\mathrm{mg} \mathrm{dm}^{-3}\right)^{\mathrm{a}}$ & 3.44 & 1.88 \\
$\mathrm{Fe}\left(\mathrm{mg} \mathrm{dm}^{-3}\right)$ & 4.97 & 246.40 \\
$\mathrm{Mn}\left(\mathrm{mg} \mathrm{dm}^{-3}\right)$ & 19.51 & 53.94 \\
$\mathrm{Cu}\left(\mathrm{mg} \mathrm{dm}^{-3}\right)$ & 0.17 & 1.15 \\
$\mathrm{Zn}\left(\mathrm{mg} \mathrm{dm}^{-3}\right)$ & 0.09 & 0.76 \\
$\mathrm{Clay}\left(\mathrm{g} \mathrm{kg}^{-1}\right)$ & 28 & 58 \\
$\mathrm{Silt}\left(\mathrm{g} \mathrm{kg}^{-1}\right)$ & 500 & 302 \\
Sand $\left(\mathrm{g} \mathrm{kg}^{-1}\right)$ & 472 & 640 \\
Organic matter $(\%)$ & 0.8 & 4.9 \\
$\mathrm{~V}(\%)$ & 100 & 83.4 \\
\hline
\end{tabular}

Note. ${ }^{\mathrm{a}} \mathrm{P}: \mathrm{Resin} 1 ;{ }^{\mathrm{b}} \mathrm{Ca}, \mathrm{Mg}$, and $\mathrm{Al}: \mathrm{KCl} 1 \mathrm{M}$ extractor.

\subsection{Experimental Design}

The experiment was conducted in a completely randomized design, in a $2 \times 2 \times 5$ factorial scheme, concerning soil types [ditch (S1) and cultivated (S2)], biostimulants [Solufull and Stimulate], and doses of soil biostimulant application at 25 days $(0,4,8,12$, and $16 \mathrm{ml})$ plus biostimulant control (no application) with six replicates of five plants. To perform the applications, biostimulants were diluted with water (4 ml biostimulant/200 $\mathrm{ml}$ water).

\subsection{Conducting the Experiment}

For substrate preparation, two types of Yellow Latosol, medium texture, collected at a depth of $0.20 \mathrm{~m}$ (Santos et al., 2018) were used. Subsequently, the soil was air dried, deforested, and sieved in $2 \mathrm{~mm}$ Tamis. $5 \mathrm{~kg}$ of tanned cattle manure was used for every $10 \mathrm{~kg}$ of soil.

For seedling production, commercial papaya seeds cultivar "Sunrise Solo" were used. Sowing was performed 30 days after substrate preparation, in $10 \times 20 \mathrm{~cm}$ plastic bags, laterally perforated, with a capacity of $0.5 \mathrm{~kg}$ of soil and three seeds per bag, at a depth of $3 \mathrm{~cm}$. The bags were placed on a slab at $1.20 \mathrm{~m}$ in height.

When the seedlings reached $5 \mathrm{~cm}$ height, thinning was done by leaving one plant per bag. Manual irrigation was performed daily. Twenty-five days after seed germination, biostimulants were applied according to the established treatments.

The biostimulants used were Solofull ${ }^{\circledR}$ and Stimulate ${ }^{\circledR}$. Solofull ${ }^{\circledR}$ (Global Crops Agri Solutions ${ }^{\circledR}$ ) is a product based on Ascophyllum nodosum (L.) Le Jolis algae, composed of $4 \%(\mathrm{w} / \mathrm{w}) \mathrm{K}_{2} \mathrm{O}, 6 \%(\mathrm{w} / \mathrm{w})$ Total Organic Carbon, $10.0 \%$ algae extract, and $0.25 \%$ citric acid. Stimulate ${ }^{\mathbb{B}}$ composition includes $0.009 \%$ kinetin; $0.005 \%$ gibberellic acid, $0.005 \%$ indolbutyric acid, and $99.98 \%$ inactive ingredients.

\subsection{Evaluations}

At 65 days after sowing, the following characteristics of vegetative growth of papaya seedlings were evaluated: $(\mathrm{H})$ height $(\mathrm{cm}),(\mathrm{SD})$ stem diameter $(\mathrm{mm})$, (NTL) number of true leaves (un), (LA) leaf area $\left(\mathrm{m}^{2}\right),(\mathrm{H} / \mathrm{SD})$ relationship plant height and stem diameter $(\mathrm{cm} / \mathrm{cm})$ and root length $(\mathrm{RL})(\mathrm{cm})$.

\subsection{Statistical Analysis}

The data were then tabulated and submitted to analysis of variance, by Tukey's test at $p<0.01$ of probability, to diagnose a significant effect and the interaction between factors in the ExpDes.pt package of software R, version 3.2.5 (R Core Team, 2018). 


\section{Results}

The analysis of variance in the present study showed that the soil type had a significant effect on the evaluated characteristics, except for root length. Presenting a simple effect in relation to the height, diameter, and significant difference $(p<0.05)$ according to the Tukey test (Table 2). The application of Solufull ${ }^{\circledR}$ and Stimulate ${ }^{\circledR}$ biostimulants significantly influenced the height and diameter variables, with no interaction regarding their application doses. The interaction between the three factors analyzed, soil, biostimulant and the application doses of the biostimulant, was significant only in the variable leaf area (Table 2).

Table 2. Summary of the analysis of variance of the variables of Carica papaya $\mathrm{L}$.

\begin{tabular}{|c|c|c|c|c|c|c|c|}
\hline \multirow{2}{*}{ Source of variation } & \multirow{2}{*}{ DF } & \multicolumn{6}{|c|}{ Pr $>$ Fc } \\
\hline & & $\mathbf{H}$ & SD & LN & LA & H/SD & RL \\
\hline Soil (S) & 1 & $0.00^{*}$ & $0.00^{* *}$ & $0.00^{*}$ & $0.00^{*}$ & $1 \mathrm{e}-04$ & $0.64^{\mathrm{ns}}$ \\
\hline Bio-stimulant (BS) & 1 & $0.06^{\mathrm{ns}}$ & $0.02^{* *}$ & $0.38^{\mathrm{ns}}$ & $0.13^{\mathrm{ns}}$ & $0.60^{\text {ns }}$ & $0.36^{\mathrm{ns}}$ \\
\hline Dose of bio-stimulant (DB) & 4 & $0.00^{*}$ & $0.04^{* *}$ & $0.55^{\mathrm{ns}}$ & $0.01^{*}$ & $0.28^{\mathrm{ns}}$ & $0.42^{\mathrm{ns}}$ \\
\hline $\mathrm{S} * \mathrm{BS}$ & 1 & $0.08^{\mathrm{ns}}$ & $0.01^{*}$ & $0.02^{* *}$ & $0.23^{\mathrm{ns}}$ & $0.44^{\mathrm{ns}}$ & $0.45^{\mathrm{ns}}$ \\
\hline $\mathrm{S} * \mathrm{DB}$ & 4 & $0.01^{*}$ & $0.00^{*}$ & $0.32^{\mathrm{ns}}$ & $0.00^{*}$ & $0.93^{\mathrm{ns}}$ & $0.96^{\mathrm{ns}}$ \\
\hline $\mathrm{BS} * \mathrm{DB}$ & 4 & $0.19^{\mathrm{ns}}$ & $0.55^{\mathrm{ns}}$ & $0.96^{\mathrm{ns}}$ & $0.08^{\mathrm{ns}}$ & $0.64^{\mathrm{ns}}$ & $0.95^{\mathrm{ns}}$ \\
\hline $\mathrm{S} * \mathrm{BS} * \mathrm{DB}$ & 4 & $0.53^{\mathrm{ns}}$ & $0.34^{\mathrm{ns}}$ & $0.76^{\mathrm{ns}}$ & $0.04^{* *}$ & $0.91^{\text {ns }}$ & $0.22^{\mathrm{ns}}$ \\
\hline Residue & 80 & & & & & & \\
\hline $\mathrm{CV}(\%)$ & & 19.13 & 70.53 & 32.93 & 16.82 & 43.05 & 17.99 \\
\hline
\end{tabular}

Note. ${ }^{*}$ Significant at $p<0.01,{ }^{* *}$ Significant $p<0.05,{ }^{\text {ns }}$ not significant.

The variable leaf area stood out in relation to the others, with soil 1 in both biostimulants showing significant difference $(p<0.05)$ according to the Tukey test in all applied doses (Table 2). According to Wally et al. (2013), the use of algae based biostimulants stimulates the production of cytokinins, phytohormones responsible for cell division and, consequently, leaf expansion.

There was no significant difference for the biostimulants, in relation to the applied dose, and the average values of the treatments $(0,4,8,12$, and $16 \mathrm{ml})$ did not differ from the control $(0 \mathrm{ml})$ (Tables 3$)$. The similar reactions of the biostimulants between the doses of application caused little variations in the metabolism and in the physiology of the plants, which in turn showed uniform development.

Table 3. Split of interaction of soil * bio-stimulant * type of application in the leaf area variable

\begin{tabular}{llllll}
\hline Stimulate $^{\circledR}$ & \multicolumn{5}{l}{ Application dose of biostimulant } \\
\hline Soil (S) & $0 \mathrm{ml}$ & $4 \mathrm{ml}$ & $8 \mathrm{ml}$ & $12 \mathrm{ml}$ & $16 \mathrm{ml}$ \\
Soil ditch (S1) & $19.11 \mathrm{a}$ & $10.19 \mathrm{a}$ & $13.35 \mathrm{a}$ & $13.74 \mathrm{a}$ & $16.46 \mathrm{a}$ \\
Cultivated (S2) & $3.42 \mathrm{~b}$ & $3.38 \mathrm{~b}$ & $4.06 \mathrm{~b}$ & $2.82 \mathrm{~b}$ & $2.51 \mathrm{~b}$ \\
\hline Solofull $^{\circledR}$ & Application dose of biostimulant & & \\
\hline Soil (S) & $0 \mathrm{ml}$ & $4 \mathrm{ml}$ & $8 \mathrm{ml}$ & $12 \mathrm{ml}$ & $16 \mathrm{ml}$ \\
Soil ditch (S1) & $13.09 \mathrm{a}$ & $8.91 \mathrm{a}$ & $13.15 \mathrm{a}$ & $18.41 \mathrm{a}$ & $10.34 \mathrm{a}$ \\
Cultivated (S2) & $3.17 \mathrm{~b}$ & $2.99 \mathrm{~b}$ & $3.21 \mathrm{~b}$ & $2.65 \mathrm{~b}$ & $3.08 \mathrm{~b}$ \\
\hline
\end{tabular}

Note. Mean values followed by the same letter are not significantly different $(p<0.05)$ according to Tukey's test.

This fact may be associated with the 65-day experimental time that according to Reis, Rodrigues, and Reis (2016) is insufficient for a promising response regarding the application of biostimulants. Similar data were observed by Nogueira et al. (2019), when evaluating the seedling production of Passiflora edulis under the use of biostimulants in different application routes. 
Table 4. Unfolding of bio-stimulant factor within each soil level and type of application in the variable leaf area

\begin{tabular}{llllll}
\hline Soil ditch & \multicolumn{5}{l}{ Application dose of bio-stimulant } \\
\hline Bio-stimulant & $0 \mathrm{ml}$ & $4 \mathrm{ml}$ & $8 \mathrm{ml}$ & $12 \mathrm{ml}$ & $16 \mathrm{ml}$ \\
Stimulate $^{\circledR}$ & $19.11 \mathrm{aA}$ & $10.19 \mathrm{aB}$ & $13.35 \mathrm{aAB}$ & $13.74 \mathrm{bAB}$ & $16.46 \mathrm{aA}$ \\
Solofull $^{\circledR}$ & $13.09 \mathrm{bAB}$ & $8.91 \mathrm{aB}$ & $13.15 \mathrm{aAB}$ & $18.41 \mathrm{aA}$ & $10.34 \mathrm{bB}$ \\
\hline Soil cultivated & Application dose of bio-stimulant & & \\
\hline Bio-stimulant & $0 \mathrm{ml}$ & $4 \mathrm{ml}$ & $8 \mathrm{ml}$ & $12 \mathrm{ml}$ & $16 \mathrm{ml}$ \\
Stimulate $^{\circledR}$ & $3.42 \mathrm{aA}$ & $3.38 \mathrm{aA}$ & $4.06 \mathrm{aA}$ & $2.82 \mathrm{aA}$ & $2.51 \mathrm{aA}$ \\
Solofull $^{\circledR}$ & $3.17 \mathrm{aA}$ & $2.99 \mathrm{aA}$ & $3.21 \mathrm{aA}$ & $2.65 \mathrm{aA}$ & $3.08 \mathrm{aA}$ \\
\hline
\end{tabular}

Note. The mean values followed by the same lowercase letter in the column and uppercase in the row do not differ statistically $(p<0.05)$ according to Tukey's test.

The interaction between soil and biostimulant was significant $(p<0.05)$ only for the variable's diameter and number of leaves, with soil 1 and the biostimulant Stimulate ${ }^{\circledR}$ standing out in both variables analyzed (Tables 5 and 6). Dantas et al. (2012) when evaluating the use of Stimulate ${ }^{\circledR}$ in the initial growth of Tamarindus indica L. observed an increase in height, dry mass of the aerial part and root system, with application of the biostimulant via leaf.

Table 5. Split of interaction of soil * bio-stimulant

\begin{tabular}{|c|c|c|c|c|}
\hline \multirow{3}{*}{ Soil } & \multicolumn{4}{|c|}{ Bio-stimulant } \\
\hline & \multicolumn{2}{|c|}{ Stem diameter $(\mathrm{cm})$} & \multicolumn{2}{|c|}{ Number of leaves } \\
\hline & Stimulate $^{\circledR}$ & Solofull $^{\circledR}$ & Stimulate $^{\circledR}$ & Solofull $^{\circledR}$ \\
\hline Soil ditch (S1) & $3.38 \mathrm{aA}$ & $3.06 \mathrm{aB}$ & $7.80 \mathrm{aA}$ & $7.16 \mathrm{aB}$ \\
\hline Cultivated (S2) & $1.68 \mathrm{bA}$ & $1.69 \mathrm{bA}$ & $5.96 \mathrm{bA}$ & $6.24 \mathrm{bA}$ \\
\hline
\end{tabular}

Note. The mean values followed by the same lower-case letter in the row and upper case in the column do not differ statistically $(p<0.05)$ according to Tukey's test.

Table 6. Split of interaction of soil * dose of application

\begin{tabular}{llllll}
\hline Plant height (cm) & \multicolumn{4}{l}{ Application dose of bio-stimulant } \\
\hline Soil (S) & $0 \mathrm{ml}$ & $4 \mathrm{ml}$ & $8 \mathrm{ml}$ & $12 \mathrm{ml}$ & $16 \mathrm{ml}$ \\
Soil ditch (S1) & $20.67 \mathrm{aA}$ & $15.08 \mathrm{aB}$ & $18.68 \mathrm{aA}$ & $19.55 \mathrm{aA}$ & $19.05 \mathrm{aA}$ \\
Cultivated (S2) & $11.35 \mathrm{bA}$ & $10.64 \mathrm{bA}$ & $11.83 \mathrm{bA}$ & $10.27 \mathrm{bA}$ & $10.71 \mathrm{bA}$ \\
\hline Stem diameter (cm) & Application dose of bio-stimulant & & \\
\hline Soil (S) & $0 \mathrm{ml}$ & $4 \mathrm{ml}$ & $8 \mathrm{ml}$ & $12 \mathrm{ml}$ & $16 \mathrm{ml}$ \\
Soil ditch (S1) & $3.46 \mathrm{aA}$ & $2.77 \mathrm{aB}$ & $3.12 \mathrm{aAB}$ & $3.46 \mathrm{aA}$ & $3.30 \mathrm{aA}$ \\
Cultivated (S2) & $1.68 \mathrm{bA}$ & $1.72 \mathrm{bA}$ & $1.76 \mathrm{bA}$ & $1.61 \mathrm{bA}$ & $1.63 \mathrm{bA}$ \\
\hline
\end{tabular}

Note. The mean values followed by the same lowercase letter in the column and uppercase in the row do not differ statistically $(p<0.05)$ according to Tukey's test.

\section{Discussion}

This may be related to the time required for the evaluation, since the balanced use of plant stimulants provides a synergistic effect on different plant organs, inducing cell division, differentiation, and elongation (Fagan et al., 2015). In this way, biostimulants act as inducing substances that undergo simultaneous changes, capable of causing different responses at different dosages and stages of plant development (Neumann et al., 2017).

However, according to Neumann et al. (2017), young tissues tend to better show the results of the application of the biostimulant in a short period of time, as they present total metabolic performance, producing more chlorophyll and, consequently, more basic structures for the supply of metabolizable energy, which will be used in the process of cell division and differentiation. Corroborating with the data found in this study (Table 4), it appears that the leaf 
area was the only variable evaluated that showed significance regarding the interaction of factors, soil, biostimulant, and applied dose.

Silva et al. (2016) observed that when applying doses greater than $2.0 \mathrm{ml} \mathrm{L}^{-1} \mathrm{H}_{2} \mathrm{O}$ of the extract of $A$. nodosum, in Annona glabra seedlings, the number of leaves and dry matter of the aerial part tends to decrease, depending on the condition of salt stress caused by higher doses. In papaya seedlings, the ideal dose for shoot dry matter verified by Guimarães et al. (2015) was $5.97 \mathrm{ml} \mathrm{L}^{-1}$ of the Root ${ }^{\circledR}$ biostimulant, showing decreasing results for higher doses.

In the interaction between soil and application dose, soil 1 was superior to soil 2 in both variables, plant height and stem diameter, with no significant difference in terms of application rates, with the dose of 4 ml lower than the others (Table 6). Silva et al. (2014) when evaluating the application of Stimulate ${ }^{\circledR}$ from the concentration of $5 \mathrm{ml}$ in watermelon cv. "Sweet Crimson," observed an increase in the percentage of normal seedlings.

It can be seen that the application of the biostimulant directly influenced the growth of papaya seedlings and the fact that there is interactivity between the factors studied is indicative of the divergence of nutritional requirements in the present materials studied (Guimarães et al., 2015). Such results corroborate those observed by Sá et al. (2013), where the authors also observed different growth responses between papaya cultivars under doses of biofertilizer in hydroponic cultivation.

\section{Conclusion}

It was found that the cultivation of papaya seedlings cultivating "Sunrise Solo" in soil in the process of degradation promoted a significant increase in the aerial part.

The types of biostimulants and application rates used in this study did not provide significant differences between treatments, under the conditions in which the seedlings were produced.

\section{References}

Calvo, P., Nelson, L., \& Kloepper, J. W. (2014). Agricultural uses of plant biostimulants. Plant and Soil, 383, 3-41. https://doi.org/10.1007/s11104-014-2131-8

Costa Junior, E. S., Matias, S. S R., Sousa, S. J. C., Santos, G. B., Morais, D. B., \& Nascimento, A. H. (2017). Production of seedlings of Carica papaya, 'formosa' type, with residues of buriti wood (Mauritia flexuosa L.f.). Agrarian Science Journal, 40, 746-755. https://doi.org/10.19084/RCA16152

Dantas, A. C. V. L., Queiroz, J. M. O., Vieira, E. L., \& Almeida, V. O. (2012). Effect of gibberellic acid and the biostimulant stimulate ${ }^{\circledR}$ on the initial growth of tamarind. Revista Brasileira de Fruticultura, 34, 08-14. https://doi.org/10.1590/S0100-29452012000100004

Du Jardim, P. (2015). Plant biostimulants: definition, concept, main categories and regulation. Scientia Horticulturae, 196, 3-14. https://doi.org/10.1016/j.scienta.2015.09.021

Fagan, E. B., Ono, E. O., Rodrigues, J. D., Chalfun Junior, A., \& Dourado Neto, D. (2015). Plant physiology: Vegetable regulators (1st ed., p. 300). São Paulo, SP: Andrei Editora LTDA.

FAO. (2018). Statistics of the United Nations Food and Agriculture Fund. Retrieved August 25, 2019, from http://faostat3.fao.org/faostat-gateway/go/to/download/Q/QC/S

Guimarães, I. P. (2012). Evaluation of the use of seaweed extract (Raiza ${ }^{\circledR}$ ) in the development of papaya seedlings. Biosphere Encyclopedia, 8, 312-320.

Guimarães, I. P., Paiva, E., Almeida, J. P. N., Arrais, I. G., Cardoso, E. A., \& Sá, F. V. S. (2015). Production of Seedling of three accessions of papaya under increasingdose of Biostimulant Root ${ }^{\circledR}$. Agrarian Science Journal, 38, 414-421.

IBGE. (2018). Sidra. Retrieved September 3, 2019, from http://www.sidra.ibge.gov.br/bda/agric

INMET (National Institute of Meteorology). (2018). Retrieved January 20, 2020, from http://www.inmet.gov.br/ sonabra/pg_dspDadosCodigo_sim.php?QTMyNg==

Jesus, V. A. M., Araujo, E. F., Santos, F. L., Alves, E., \& Dias, L. A. S. (2015). Sodium hypochlorite for sarcotesta remotion from papaya seeds: anatomical studies. Journal of Seed Science, 37, 228-235. https://doi.org/10.1590/2317-1545v37n4153890

Koppen, W., \& Geiger, R. (1928). Klimate der Erde (1st ed.). Gotha: Verlag Justus Perthes.

Lessa, B. F. T., Almeida, J. P. N., Paiva, E. P., Oliveira, D. M., Toste, M. S., \& Mendoça, V. (2013). Mycorrhizal fungus inoculation in seeds of two papaya accessions for seedling production. Brazilian Journal of Agricultural Sciences, 8, 236-240. https://doi.org/10.5039/agraria.v8i2a2709 
Melo, A. P. C., Seleguini, A., Pereira, J. M., Neto, A. R., Wisintainer, C., Neves, R. G., \& Camilo, Y. M. V. (2015). Fruit ripening and pre-germination in seedlings of papaya. Agrarian Science Journal, 38, 330-337.

Neumann, E. R., Resende, J. T. V., Camargo, L. K. P., Chagas, R. R., \& Lima Filho, R. B. (2017). Production of sweet potato seedlings in protected environment with application of Ascophyllum nodosum extract. Brazilian Horticulture, 35, 490-498. https://doi.org/10.1590/s0102-053620170404

Nguyen, V. H., \& Yen, C. R. (2018). Rootstock age and grafting season affect graft success and plant growth of papaya (Carica papaya L.) in greenhouse. Chilean Journal Agricultural Research, 78, 59-67. https://doi.org/10.4067/S0718-58392018000100059

Nogueira, M. S., Matias, S. S. R., Evangelista, T. Y. L., Monte Junior, F. A. C., \& Barros, B. A. A. (2019). Bio-stimulants in the production of passiflora edulis seedlings. Asian Academic Research Journal of Multidisciplinary, 6, 1-11.

R Core Team. (2018). R: A language and environment for statistical computing. R Foundation for Statistical Computing, Vienna, Austria. Retrieved November 10, 2018, from https://www.R-project.org

Reis, J. M. R., Rodrigues, J. F., \& Reis, M. A. (2016). Doses and forms of application of biostimulant in the production of passion fruit seedlings. Agronomic Crop Journal, 35, 267-274

Sá, F. V. S., Mesquita, E. F., Bertino, A. M. P., Silva, G. A., \& Costa J. D. (2013). Biofertilizers in the hydroponic production of papaya seedlings. Green Journal of Agroecologyy and Sustainable Development, $8,109-116$.

Santos, H. G. (2018). Brazilian system of soil classification (p. 353). National Soil Research Center, Rio de Janeiro, RJ.

Silva, C. C., Arrais, I. G., Almeida, J. P. N., Dantas, L. G. R., Francisco, S. O., \& Mendonça, V. (2016). Ascophyllum nodosum (L.) Le Jolis seaweed extract in the production of rootstocks by Anonna glabra L. Agricultural Sciences Journal, 38, 234-247. https://doi.org/10.19084/RCA15057

Silva, M. J. R., Bolfarini, A. C. B., Rodrigues, L. F. O., Ono, E. O., \& Rodrigues, J. D. (2014). Formation of watermelon seedlings as a function of different concentrations and forms of application of a mixture of plant regulators. Scientia Plena Journal, 10, 1-9.

Wally, O. S. D., Critchley, A. T., Hiltz, D., Craigie, J. S., Han, X., Zaharia, L. I., ... Prithiviraj, B. (2013). Regulation of phytohormone biosynthesis and accumulation in arabidopsis following treatment with commercial extract from the marine Macroalga Ascophyllum nodosum. Journal of Plant Growth Regulation, 32, 324-339. https://doi.org/10.1007/s00244=012-9311-7

\section{Copyrights}

Copyright for this article is retained by the author(s), with first publication rights granted to the journal.

This is an open-access article distributed under the terms and conditions of the Creative Commons Attribution license (http://creativecommons.org/licenses/by/4.0/). 